„Ante Portas - Studia nad Bezpieczeństwem”

DOI: $10.33674 / 2201910$

Marek LESZCZYŃSKI ${ }^{1}$

Polska

\title{
BEZPIECZEŃSTWO EKONOMICZNE, ZMIANY KLIMATYCZNE, WYZWANIA
}

\author{
(ECONOMIC SECURITY, CLIMATIC CHANGES, CHALLENGES)
}

\begin{abstract}
Abstrakt:
Bezpieczeństwo ekonomiczne stanowi jedno z głównych obszarów badań przedstawicieli nauk o bezpieczeństwie, jego poziom jest warunkowany wieloma czynnikami o charakterze ekonomicznym, politycznym, prawnym czy kulturowym. $W$ artykule wskazano na uwarunkowania zwiazane z procesem ocieplania klimatu $i$ ich znaczenie dla kształtowania bezpieczeństwa ekonomicznego. Jako hipoteze przyjęto, iz niezbędne jest dokonanie istotnej zmiany $w$ zakresie ksztattowania modelu konsumpcji oraz roli państwa $w$ ksztaltowaniu procesów rozwoju stużącego tworzeniu potęgi ekonomicznej przy jednoczesnym zrównoważonym podejściu do wykorzystania zasobów przyrodniczych. Artykut ma charakter przegladowy, celem jest wskazanie na konieczność zmiany na bardziej aktywna role państwa $w$ ksztaltowaniu bezpieczeństwa $i$ tadu ekonomicznego. W tym kontekście wykorzystanie dorobku wypracowanego przez szwedzka szkote ekonomii oraz skandynawskie studia na pokojem (w tym zwłaszcza ekonomike pokoju) stać się może podstawa do stworzenia modelu rozwoju wykorzystującego podejście godzace interesy ekonomiczne, przyrodnicze i instytucjonalne. Tworzenie podstaw bezpieczeństwa ekonomicznego państwa musi w sposób pragmatyczny i odpowiedzialny uwzględniać ograniczoność zasobów przyrodniczych i jednocześnie uwzględniać cele spoleczne zwiąane z jakościa życia ludzi.
\end{abstract}

\section{Stowa kluczowe:}

bezpieczeństwo ekonomiczne, rozwój, ekonomika pokoju

\footnotetext{
${ }^{1}$ Marek Leszczyński, dr hab., profesor Uniwersytetu Jana Kochanowskiego, ekonomista, specjalizuje się w bezpieczeństwie społecznym i ekonomicznym. Email: marekle@ujk.edu.pl ORCID: 0000-0002-4951-1974.
} 


\section{Abstract:}

Economic security constitutes one of the main areas of research carried out by representatives of security studies. Its level is conditioned by many factors of economic, political, law or cultural character. The article points out the conditions connected with the process of climate warming and their meaning for shaping the economic security. As a hypothesis it has been assumed that it is crucial to make a significant change in the scope of shaping the consumption model and the role of the state in shaping the processes of development. It serves the creation of economic force with a simultaneous balanced approach to the use of natural resources. The article has a review character, it's aim is to indicate the necessity of a change into the more active role of the state in shaping the security and economic order. In this context, the use of works developed by the Swedish school of economy and Scandinavian studies over peace (including mainly the peace economics) can become the basis to create the development model which uses the approach that connects the economic, natural and institutional interests. The creation of economic security bases of a state must, in a pragmatic and responsible way, include the limitation of natural resources and at the same time take into account the social aims connected with the quality of people's lives.

\section{Keywords:}

economic security, development, peace economics

\section{Wprowadzenie}

Bezpieczeństwo ekonomiczne stanowi jedno z głównych obszarów badań przedstawicieli nauk o bezpieczeństwie, poziom bezpieczeństwa ekonomicznego kraju jest warunkowany wieloma czynnikami o charakterze ekonomicznym, politycznym, prawnym czy kulturowym. W artykule wskazano na uwarunkowania związane $\mathrm{z}$ procesem ocieplania klimatu i ich znaczenie dla kształtowania bezpieczeństwa ekonomicznego. Wśród specjalistów toczy się dyskusja, na ile obserwowane zmiany klimatyczne wiązać można jedynie $\mathrm{z}$ działalnością człowieka a na ile przyczyny mają charakter niezależny - naturalny cykl życia Ziemi czy zmiany na słońcu. Zmiany klimatyczne wywołują określone skutki dla m.in. bezpieczeństwa żywnościowego, procesów migracyjnych, roli państw i aktorów pozapaństwowych w kształtowaniu systemów współczesnego bezpieczeństwa. Jako hipotezę przyjęto, iż niezbędne jest dokonanie istotnej zmiany w zakresie kształtowania modelu konsumpcji oraz roli państwa w kształtowaniu procesów rozwoju służącego tworzeniu potęgi ekonomicznej przy jednoczesnym zrównoważonym podejściu do wykorzystania zasobów przyrodniczych. Nieodpowiedzialne podejście do zasobów przyrody stwarza 
napięcia o charakterze społecznym, będąc jedną $\mathrm{z}$ głównych przyczyn współczesnych konfliktów konfliktów.

\section{Wzrost i rozwój gospodarczy, kształtowanie bezpieczeństwa ekonomicznego kraju}

Ekonomiści zajmujący się bezpieczeństwem prowadzą badania $\mathrm{w}$ dwóch głównych nurtach badań: ekonomice bezpieczeństwa i ekonomice pokoju. Pierwsza z nich jest lepiej znana w Polsce, ma swój rodowód w ekonomice obrony wykładanej na studiach ekonomicznych w Polsce przez wiele lat. Ekonomika bezpieczeństwa jest szczegółową dyscypliną naukową, badającą formy i metody przygotowania i funkcjonowania gospodarki gotowej do spełnienia zadań z zakresu bezpieczeństwa. Przedmiotem zainteresowania ekonomiki bezpieczeństwa jest kształtowanie gospodarki narodowej w warunkach trzech stanów: pokoju, kryzysu oraz wojny ${ }^{2}$. W warunkach współczesnych szczegółowe problemy badawcze J. Płaczek formułuje jako:

- podział obciążeń obronnych w ramach sojuszu;

- system kierowania zasobami obronnymi w okresie kryzysu;

- kształtowanie bezpieczeństwa ekonomicznego państwa (żywnościowe, finansowe, surowcowo-energetyczne);

- współpraca cywilno-wojskowa w zakresie wypełniania zadań państwagospodarza;

- ekonomiczno-techniczne warunki wsparcia sił w czasie klęsk żywiołowych;

- skuteczność współczesnych środków wojny gospodarczej;

- społeczno-ekonomiczne koszty konwersji przemysłu zbrojeniowego;

- klasyfikację i wykorzystanie surowców strategicznych;

- rekonwersję personelu sił zbrojnych ${ }^{3}$.

Druga wspomniana dyscyplina - ekonomika pokoju wywodzi się ze studiów nad pokojem, w tym zwłaszcza pokoju pozytywnego w ujęciu Johana Galtunga. Ekonomika pokoju ma charakter normatywny - wskazuje jak być powinno, a nie jak jest. Ekonomika pokoju dotyczy ekonomicznego studiowania i projektowania instytucji politycznych, gospodarczych i kulturalnych, ich wzajemnych powiązań i ich polityk w celu zapobiegania, łagodzenia lub rozwiązywania wszelkiego rodzaju ukrytych lub rzeczywistych destrukcyjnych konfliktów wewnątrz i między społeczeństwami ${ }^{4}$.

${ }^{2}$ J. Płaczek, Metodyczne podstawy ekonomiki bezpieczeństwa, [w:] Ekonomika bezpieczeństwa państwa w zarysie, J. Płaczek (red.), Warszawa 2014, s. 44.

${ }^{3}$ Ibidem, s. 45.

${ }^{4}$ J. Brauer, R. Caruso, Peace economists and peace economics, Working Paper. Draft (v. 5), 21.11.2011 Draft chapter for Roger MacGintry (ed.) Handbook on Peacebuilding, Londyn 2011. 
Dość naiwna wiara w stały postęp ekonomiczno-społeczny, która przyświecała ekonomii głównego nurtu zaczęła ulegać zmianie stosunkowo niedawno. Co prawda już ekonomiści związani ze szkołą szwedzką i ekonomią rozwoju akcentowali w latach 60. konieczność bardziej odpowiedzialnego podejścia do gospodarowania to jednak zdefiniowanie zrównoważonego rozwoju nastąpiło dopiero w 1972 roku na konferencji ONZ „Środowisko a dobrobyt ludzkości”. Mianem rozwoju zrównoważonego określono zaspokojenie podstawowych potrzeb wszystkich ludzi łącząc tę kwestie z zachowaniem równowagi ekosystemu $\mathrm{w}$ perspektywie następnych pokoleń ${ }^{5}$. Rozwój zrównoważony wymaga holistycznego ujmowania celów i działań w oparciu o inkluzywność, dostęp społeczności różnych państw do globalnych korzyści wynikających z wymiany międzynarodowej a także nieprzekraczaniu granic wydolności środowiska naturalnego ${ }^{6}$. Jednocześnie pisząc o rozwoju zrównoważonym należy rozróżnić dwa zasadniczo różne kategorie ekonomiczne, a mianowicie wzrost i rozwój gospodarczy. Wzrost gospodarczy jest to powiększanie się zdolności wytwórczych gospodarki związane z wielkością produkcji dóbr i usług. Poziom wzrostu gospodarczego zależy od wielu czynników o charakterze ekonomicznym takich jak: wielkość zasobów kapitału, stopy oszczędności i inwestycji w gospodarce, postępu technicznego, poziomu kapitału ludzkiego czy sprawności instytucji ${ }^{7}$. Natomiast pojęcie rozwoju gospodarczego jest znacznie szersze. O ile wzrost gospodarczy mierzony jest zmianami o charakterze ilościowym, to rozwój gospodarczy opisywany jest zmianami jakościowymi. Zmiany te mają charakter strukturalny $\mathrm{i}$ instytucjonalny. Chodzi tu o zmiany w strukturze branżowej i gałęziowej, zmiany $\mathrm{w}$ strukturze zatrudnienia w układzie sektorów gospodarki, zmiany w charakterze podaży dóbr i popytu na dobra i usługi w danym czasie. Rozwój gospodarczy ma zatem charakter złożony. Wymaga stosownych impulsów zarówno o charakterze endo-, jak i egzogenicznym. Procesowi wieloletniego wzrostu gospodarczego nie musi towarzyszyć rozwój ekonomiczno-społeczny. Sam wzrost gospodarczy bez zmian o charakterze jakościowym związany z koniecznością zmian zachowań i postaw podmiotów na rynku, może jedynie petryfikować przestarzałą strukturę gospodarki. O ile koncentrowanie się na wzroście gospodarczym w krajach o niskim poziomie rozwoju może mieć swoje uzasadnienie, o tyle lekceważenie

5 E. Frejtag-Mika, K. Sieradzka, Granice wzrostu gospodarczego - dylematy współczesności, [w:] Globalizacja i regionalizacja we współczesnym świecie. Wyzwania integracji i rozwoju, (red.) E. Molendowski, A. Mroczek, Warszawa 2015, s. 17.

${ }^{6}$ W. Rutkowski, Nierówności ekonomiczne a rozwój gospodarczy i dobrobyt społeczny, "Ekonomista" nr 2/2016, s. 171.

${ }^{7}$ J. Kot, Wzrost $i$ rozwój gospodarczy w warunkach globalizacji i umiędzynarodowienia, [w:] Zarzadzanie $i$ gospodarka. Wybrane zagadnienia $i$ procesy. Wybrane aspekty wspótczesnej gospodarki, (red.) J. Kot, Kielce 2016, ss. 9-10. 
zmiennych jakościowych w krajach o co najmniej średnim poziomie rozwoju i średnim dochodzie jest wysoce nieuzasadniony.

Złożoność procesu rozwoju ekonomiczno-społecznego wynika z konieczności uwzględniania różnych czynników o charakterze rozwojowym takich jak:

- polityki gospodarczej;

- reguł gry, w ramach których funkcjonuje gospodarka;

- kultury organizacji;

- wyznawanych wartości;

- stosunków społecznych, stosowanych technik i technologii;

- ryzyka przedsięwzięć;

- oddziaływań środowiskowych;

- sposobów zarządzania ${ }^{8}$.

Minione lata, po kryzysie energetycznym z początku lat siedemdziesiątych XX wieku upłynęły pod hasłem globalizacji procesów gospodarczych. Wyłonił on nowych aktorów w architekturze gospodarki światowej, którzy będą mieli prawdopodobnie kluczowe znaczenie dla kształtowania procesów rozwoju w obecnym stuleciu. Niewątpliwie należą do nich Chiny i Indie, ale także inne państwa Azji oraz o czym należy pamiętać podmioty pozapaństwowe korporacje transnarodowe?

Tabela 1: Prognoza zmian w gospodarce światowej w latach 2004-2050 (udziat $w$ światowym PKB w\%)

\begin{tabular}{|l|l|l|l|}
\hline Podmiot & $\mathbf{2 0 0 4}$ & $\mathbf{2 0 2 5}$ & $\mathbf{2 0 5 0}$ \\
\hline Chiny & 4 & 15 & 28 \\
\hline Stany Zjednoczone & 28 & 27 & 26 \\
\hline Indie & 2 & 5 & 17 \\
\hline Unia Europejska & 34 & 25 & 15 \\
\hline Japonia & 12 & 7 & 4 \\
\hline reszta świata & 20 & 21 & 10 \\
\hline Świat & 100 & 100 & 100 \\
\hline
\end{tabular}

Źródło: J. Kot, Wzrost $i$ rozwój gospodarczy $w$ warunkach globalizacji $i$ umiędzynarodowienia, [w:] Zarzadzanie i gospodarka. Wybrane zagadnienia i procesy. Wybrane aspekty wspótczesnej gospodarki, J. Kot (red.), Kielce 2016, s. 16.

\footnotetext{
${ }^{8}$ E. Frejtag-Mika, K. Sieradzka, op. cit., s. 18; także G. Kołodko, Wędrujacy świat, Warszawa 2008.

${ }^{9}$ M. Leszczyński, Wrost $i$ rozwój gospodarczy a problem zatrudnienia $w$ gospodarce czarnorynkowej, „Roczniki Ekonomii i Zarządzania, Towarzystwo Naukowe Kul, Katolicki Uniwersytet Lubelski Jana Pawła II", Tom 10(46), nr 2, 2018, ss. 9-10.
} 
Rzeczywistość globalizacji wyłania nowy obraz konkurencji między podmiotami, tym procesom towarzyszy jednak dysproporcjonalny rozwój. Unifikacja i standaryzacja modeli biznesu, ale także innych sfer ludzkiej działalności przynosi obok korzyści również szereg napięć i konfliktów związanych z dysproporcjami społecznymi, ekonomicznymi i politycznymi. M.G. Woźniak wymienia jako znaczące następujące procesy, które stanowią swoisty koszt modernizacji i globalizacji dla wielu gospodarek ${ }^{10}$ :

- nierównomierne rozkładanie się kosztów i korzyści modernizacji;

- narastanie ryzyka zagrożeń dla przyszłych pokoleń w postaci: głodu i ubóstwa, wykluczenia przez utratę pewnych praw, katastrof naturalnych w ekosferze i spowodowanych deficytem niektórych surowców, genetycznych, epidemii biologicznych, informatycznych, związanych z radioaktywnością, kryzysu demograficznego, terroryzmu i lokalnych konfliktów, relatywnego spadku wydajności pracy, piractwa własności intelektualnej, negatywnych skutków ekspansji potrzeb nieelementarnych, relatywizmu moralnego;

- konfrontacja neoliberalnych reguł gry, związana z konfliktem procesów o charakterze globalnym z tradycyjnymi zwyczajami, sposobem pracy, systemem wartości, kulturą społeczeństwa przemysłowego - „walka” idei postmodernizmu i ponowoczesności z tradycjami epoki przemysłowej.

Do powyższych zagrożeń dodać można kwestię polaryzacji rozwoju ekonomicznego w świecie przy ogólnym postępie w walce ze skrajnym ubóstwem. Jednocześnie $\mathrm{w}$ zasadniczy sposób zmienia się funkcja państwa narodowego a także postrzeganie jego roli dystrybucyjnej. Nastąpiła zasadnicza zmiana i ewolucja tzw. państwa dobrobytu związana m.in. z deindustrializacją i globalizacją.

\section{Ekonomizacja bezpieczeństwa. Bezpieczeństwo jako dobro publiczne}

Ekonomizacja bezpieczeństwa wynika z kilku czynników takich jak: postęp naukowo-techniczny, zmiany postrzegania i znaczenia przestrzeni dla państw (ewolucja od geopolityki w stronę geoekonomii), wzrostu rywalizacji między państwami o zasoby i kapitały. Ponadto $w$ wyniku globalizacji rosną współzależności między państwami wynikające $\mathrm{z}$ przepływów towarów, kapitałów, ludzi i idei. Wzrasta poziom zadłużenia międzynarodowego (zjawisko zależności finansowej i politycznej), pojawiają się nowi aktorzy stosunków międzynarodowych - korporacje transnarodowe, występują na szeroką skalę

\footnotetext{
${ }^{10}$ M. G. Woźniak, Holistyczna modernizacja refleksyjna kapitału ludzkiego odpowiedzia na wyzwania i zagrożenia rozwojowe współczesnej fali globalizacji, [w:] Gospodarka Polski 19990-2011. Droga do spójności społeczno-ekonomicznej, Warszawa 2012, s. 194.
} 
strefy głodu, niekontrolowanych migracji, lokalnych konfliktów zbrojnych o zasoby wody i zasoby przyrodnicze ${ }^{11}$. „W prowadzonych badaniach nad bezpieczeństwem ekonomicznym bezpieczeństwo ekonomiczne zdefiniowano jako niezakłócone funkcjonowanie gospodarek, to znaczy utrzymanie podstawowych wskaźników rozwojowych oraz zapewnienie komparatywnej równowagi z gospodarkami innych państw"12. K. M. Księżopolski wyodrębnia cztery zasadnicze wymiary bezpieczeństwa ekonomicznego: finansowy, surowcowo-energetyczny, żywnościowy oraz dostępu do czystej wody. „W ramach każdego z tych wymiarów występują zagrożenia, które wpływają na bezpieczeństwo ekonomiczne państw, czyli terytorium, ludność, władzę, suwerenność oraz poziom i jakość życia obywateli" ${ }^{13}$. Poza zagrożeniami, których źródłem są inne państwa coraz częściej obserwujemy zagrożenia ze strony aktorów pozapaństwowych, takich jak banki, fundusze inwestycyjne, różnego rodzaje lobby i grupy nacisku skupiające kapitał i władzę.

Zapewnienie bezpieczeństwa to jedna $\mathrm{z}$ podstawowych funkcji państwa, warunki jej spełnienia leżą $\mathrm{W}$ obszarze zainteresowania wspomnianej dyscypliny. Badacze min. J. Kleer wskazują, iż bezpieczeństwo stało się globalnym dobrem publicznym. Każdy człowiek ma prawo do poczucia bezpieczeństwa, mimo iż terytorium na którym mieszka nie zawsze takie poczucie zapewnia. Kształtowanie bezpieczeństwa ekonomicznego pozostaje domeną państwa narodowego, przy czym obecnie ze względu na proces globalizacji akcentuje się podejście geoekonomiczne, które w stosunkach międzynarodowych zastępuje podejście geopolityczne. Bezpieczeństwo jest przykładem dobra publicznego, o charakterze nierywalizacyjnym, z konsumpcji którego nie można wyłączyć żadnego członka danej zbiorowości. Decyzje o dostarczaniu dóbr publicznych są efektem wyborów publicznych i decyzji politycznych ${ }^{14}$. Bezpieczeństwo, będąc dobrem publicznym posiada wspólne cechy $\mathrm{z}$ innymi dobrami zaliczanymi do tej kategorii, jak użyteczność, traktowaną jako miarę satysfakcji z konsumpcji. Dostarczenie bezpieczeństwa wymaga odpowiednich środków i związanych $\mathrm{z}$ nimi nakładów w czasie. Bezpieczeństwo jako dobro publiczne warunkuje także konsumpcję innych dóbr i usług, stanowiąc dobro podstawowe oraz jednocześnie będąc dobrem komplementarnym $\mathrm{w}$ stosunku do wartości objętych przedmiotowo zakresem bezpieczeństwa. Za dostarczanie i wytwarzanie bezpieczeństwa odpowiada państwo, w wymiarze instytucjonalnym. Warunkiem skutecznego kształtowania

\footnotetext{
${ }^{11}$ K. M. Księżopolski, Bezpieczeństwo ekonomiczne - przedmiot badań i praktyka, [w:] Współczesne bezpieczeństwo ekonomiczne. Wymiar międzynarodowy, (red.) M. Gębska, M. Kubiak, Warszawa 2016, ss. 14-15.

12 Ibidem, s. 16.

${ }^{13}$ Ibidem, s. 17.

${ }^{14}$ Z. Stachowiak, Teoria i praktyka mechanizmu bezpieczeństwa ekonomicznego państwa. Ujęcie instytucjonalne, Warszawa 2012, s. 42.
} 
bezpieczeństwa jest suwerenność podmiotu, w tym przypadku państwa. „Mimo postępującej integracji i dynamiki tworzenia ugrupowań integracyjnych suwerenność pozostaje wyłącznym atrybutem państw i stanowi o istocie państwowości. Nasilenie procesów globalizacji i fragmentacji wywołało pytania dotyczące możliwości i sposobów odpowiedzi na nowe wyzwania i zagrożenia w stosunkach międzynarodowych, w tym dotyczące suwerenności państwa. Dylemat ten odnosi się w głównej mierze do dalszego funkcjonowania międzynarodowego systemu opartego na państwach narodowych i ich zdolności do skutecznego działania w globalizującym się świecie" ${ }^{15}$. Bezpieczeństwo coraz częściej traktowane jest w kategoriach globalnego dobra publicznego, ponieważ gospodarka staje się współzależna, zmieniają się zagrożenia i coraz częściej patrzy się na bezpieczeństwo z perspektywy globalnej a nie tylko narodowej. Coraz powszechniej zaczyna przyjmować się, że konsumpcja pewnych globalnych dóbr publicznych przez jedne kraje, czy ich społeczeństwa nie może uszczuplać konsumpcji tych dóbr przez inne państwa. Chodzi tu o takie dobra jak ${ }^{16}$ : woda, powietrze, pokój, zdrowie, prawo do nauki i wykształcenia, wiedzy, prawo do informacji, prawo do ludzkiego traktowania. „Globalne dobra są efektem powiązań i porozumień między co najmniej dwoma państwami, w sprawie korzystnych rozwiązań nie tylko samych podmiotów państwowych, ale i ich społeczeństw. Oznacza to, że w korzyściach uczestniczą państwa i pośrednio lub bezpośrednio również społeczeństwa tych państw, które mogą z nich korzystać zarówno jednostkowo jak tez zbiorowo"17.

Tabela 2: Klasyfikacja dóbr przy użyciu kryteriów własności, konkurencji $i$ wytaczności

\begin{tabular}{|l|l|l|}
\hline $\begin{array}{l}\text { Dobra } \\
\text { konkurencyj- }\end{array}$ & $\begin{array}{l}\text { Dobra podlegające } \\
\text { neylączeniu }\end{array}$ & $\begin{array}{l}\text { Dobra niepodlegające } \\
\text { wylączeniu }\end{array}$ \\
\cline { 2 - 3 } & $\begin{array}{l}\text { Dobra prywatne: żywność, } \\
\text { ubranie, meble, sprzęt } \\
\text { trwałego użytku }\end{array}$ & $\begin{array}{l}\text { Ogólny zbiór } \\
\text { zasobów/wspólne dobra } \\
\text { publiczne: woda, powietrze, } \\
\text { środowisko, rybołówstwo, } \\
\text { lowiectwo }\end{array}$ \\
\hline Dobra & Dobra podlegające & Dobra publiczne: obrona \\
\hline
\end{tabular}

${ }^{15}$ M. Grącik-Zajaczkowski, Suwerenność w warunkach globalizacji, [w:] (red.) K. Żukrowska, Bezpieczeństwo międzynarodowe. Przeglad aktualnego stanu, Warszawa 2011, ss. 234-246.

${ }_{16}$ Bezpieczeństwo międzynarodowe. Przeglad aktualnego stanu, (red.) K. Żukrowska Warszawa 2011, ss. 32-33.

${ }^{17}$ J. Kleer, Dobra publiczne: wczoraj-dziś-jutro, Warszawa 2015, s. 185. 


\begin{tabular}{|l|l|l|}
\hline $\begin{array}{l}\text { niekonkuren- } \\
\text { cyjne }\end{array}$ & $\begin{array}{l}\text { wyłączeniu (ekskluzywne, } \\
\text { klubowe) }\end{array}$ & $\begin{array}{l}\text { narodowa, zdrowie, nauka, } \\
\text { przekaz radiowy i } \\
\text { telewizyjny }\end{array}$ \\
\cline { 2 - 3 } & Dobra prywatne & Dobra publiczne \\
\hline
\end{tabular}

Źródło: Bezpieczeństwo międzynarodowe. Przeglad aktualnego stanu, red. K. Żukrowska, Warszawa 2011, s. 31.

\section{Zmiany klimatyczne a problem bezpieczeństwa ekonomicznego}

W nauce trwa dyskusja nad rzeczywistymi przyczynami ocieplania się klimatu, kwestią sporną pozostaje określenie wpływu działań ludzkich na ten proces - czy jest to czynnik jedyny, czy jeden z kilku. Uważa się, że trwające $\sim 120$ tys. lat oscylacje temperatury i towarzyszące im cykle lodowcowe są wywoływane przez zmiany orbity Ziemi - precesję (obrót w przestrzeni osi obrotu Ziemi, jak w kręcącym się bąku), czyli zmiany nachylenia osi obrotu Ziemi do płaszczyzny orbity oraz zmianę jej mimośrodu (oscylacje między orbitą kołową i eliptyczną). Zmiany orbity Ziemi powodują okresowe zmiany w ilości otrzymywanej od Słońca energii. Są to tzw. cykle Milankovicia, które wskazują, że klimatem Ziemi steruje energia otrzymywana Słońca. Szczególnie mocno podkreślają to sceptycy negujący wpływ człowieka na globalne ocieplenie. W długich skalach czasowych zmienia się orbita Ziemi, a w krótszych skalach czasowych (dziesiątki, setki i tysiące lat) zmiany klimatu mogą być wywoływane zmianami aktywności samego Słońca, które w ten sposób dostarcza do Ziemi mniej lub więcej energii ${ }^{18}$. Większość badaczy zwraca jednak uwagę, że rozrost populacji Ziemi, rozwój przemysłu i rolnictwa może mieć istotne znaczenie dla zmian w ekosystemie, w tym na procesy ocieplenia klimatu. Specjaliści wskazują zwłaszcza na rolę emisji tzw. gazów cieplarnianych (dwutlenek węgla i metan). Szacuje się, iż obecny poziom koncentracji dwutlenku węgla jest najwyższy od 420 tys. lat. Około $80 \%$ emisji dwutlenku węgla pochodzi ze spalania paliw kopalnych, pozostałe $20 \%$ jest efektem wycinki lasów oraz produkcją rolnictwa (zwłaszcza zwiększenie pogłowia bydła w związku ze wzmożonym popytem na mięso) ${ }^{19}$. Na skutek przyrostu liczby ludności, rozszerzenia się obszarów zurbanizowanych, zwiększania zakresu upraw oraz generalnie rozrostu działalności gospodarczej dochodzi do wzrostu temperatury przy powierzchni Ziemi. Efektem tego jest topnienie lądolodu i zalewanie terenów nadbrzeżnych skutkujące zmniejsza-

\footnotetext{
${ }^{18}$ Dlugookresowe zmiany temperatury - cykle Milankovicia, <https://ziemianarozdrozu.pl/ encyklopedia/125/wplyw-slonca-na-zmiany-temperatury-ziemi>, (27.06.2019).

${ }^{19}$ R. Bartkowiak, Ekonomia rozwoju, Warszawa 2013, ss. 199-200.
} 
niem się terenów możliwych do wykorzystania przez człowieka - zachodzi swoista kwadratura koła. Już dzisiaj około 5\% ludności świata zamieszkuje tereny zalewowe - narażone na katastrofalne powodzie i tsunami. Najsilniej zjawisko to występuje przy ujściach wielkich rzek (Indie) czy ekstremalny przypadek Bangladeszu (kraj o powierzchni połowy Polski, zamieszkały przez czterokrotnie więcej ludności, z której połowa narażona jest na powodzie i huragany). Zmiany klimatyczne wywierają już istotny wpływ na produkcję rolnictwa i jej strukturę. Na skutek podnoszenia się temperatury pojawią się możliwości upraw na terenach dotychczas zbyt zimnych (północna Rosja, Kanada), jednocześnie następuje pustynnienie wszędzie tam, gdzie temperatury są zbyt wysokie do upraw (Afryka - zagrożona pustynnieniem, które obejmie ok. $30 \%$ powierzchni kontynentu, Azja Południowa, czy Bangladesz i Indie obszary gęsto zaludnione). Ze względu na wzrost temperatury mogą zanikać uprawy pszenicy i ryżu, w ich miejsce pojawi się proso - bardziej odporne na wysokie temperatury, ale jednocześnie mniej wydajne. Jeżeli nadal będzie rosła populacja Ziemi to skutkować to może stałym niedożywieniem i klęskami głodu. Ocieplenie klimatu poprawi warunki upraw w krajach o klimacie umiarkowanym i chłodnym, a spowoduje potężne problemy w krajach już uznanych za ubogie i przeludnione.

Prawdopodobnym skutkiem tych procesów będzie wzmożona presja migracyjna (zob. tab. 3), ale także lokalne konflikty o dostęp do zasobów ziemi, wody i żywności. Nastąpi dalsza polaryzacja w rozwoju (a być może przeciętne obniżenie poziomu życia we wszystkich państwach świata).

Tabela 3: Skumulowana liczba migrantów (znak ujemny oznacza emigrację), w milionach.

\begin{tabular}{|c|c|c|c|c|c|c|c|c|}
\hline $\begin{array}{l}\text { Grupa } \\
\text { krajów }\end{array}$ & $\begin{array}{l}\text { Lata } \\
1950 \\
- \\
1960\end{array}$ & $\begin{array}{l}\text { do } \\
1970 \\
\text { roku }\end{array}$ & $\begin{array}{l}\text { do } \\
1980 \\
\text { roku }\end{array}$ & $\begin{array}{l}\text { do } \\
1990 \\
\text { roku }\end{array}$ & $\begin{array}{l}\text { do } \\
2000 \\
\text { roku }\end{array}$ & $\begin{array}{l}\text { do } \\
2010 \\
\text { roku }\end{array}$ & $\begin{array}{l}\text { do } \\
2020 \\
\text { roku }\end{array}$ & $\begin{array}{l}\text { do } \\
2030 \\
\text { roku }\end{array}$ \\
\hline $\begin{array}{l}\text { Kraje } \\
\text { zamożne }\end{array}$ & $-0,03$ & 5,5 & 16,4 & 31,7 & 56,6 & 85,6 & 108,3 & 131,0 \\
\hline $\begin{array}{l}\text { Kraje ubo- } \\
\text { gie, w tym: }\end{array}$ & 0,03 & $-5,5$ & $\begin{array}{l}-16,4 \\
\end{array}$ & $-31,7$ & $-56,6$ & $-85,6$ & $-108,3$ & $-131,0$ \\
\hline - Afryka & $-1,3$ & $-3,1$ & $-6,6$ & $-9,2$ & $-12,3$ & $-16,5$ & $-20,3$ & $-24,2$ \\
\hline - Azja & 1,9 & 1,7 & $-2,1$ & $-6,6$ & $-20,0$ & $-33,1$ & $-45,2$ & $-57,4$ \\
\hline $\begin{array}{l}\text { - Ameryka } \\
\text { Lacińska }\end{array}$ & $-0,7$ & $-3,6$ & $-7,8$ & $-15,6$ & $-23,3$ & $-34,4$ & $-40,6$ & $-46,5$ \\
\hline
\end{tabular}

Źródło: R. Bartkowiak, Ekonomia rozwoju, Warszawa 2013, s. 205. 
Ludność z obszarów dotkniętych pustynnieniem, brakiem dostępu do wody, ofiary klęk głodu nieuchronnie przemieszczać się będzie w stronę miast przyczyniając do żywiołowej urbanizacji (zob. tab. 4).

Tabela 4: Ludność miejska w\%.

\begin{tabular}{|c|c|c|c|c|c|}
\hline \multirow[t]{2}{*}{ Grupa państw, państwa } & \multicolumn{5}{|l|}{ Lata } \\
\hline & 1990 & 1950 & 2000 & 2007 & 2050 \\
\hline Świat & 14 & 29 & 47 & 50 & 70 \\
\hline Kraje zamożne & 30 & 53 & 73 & 75 & 86 \\
\hline Kraje ubogie, w tym: & 9 & 18 & 40 & 44 & 67 \\
\hline - Brazylia & - & 36 & 81 & 85 & 94 \\
\hline - Chiny & - & 13 & 36 & 42 & 73 \\
\hline - Indie & - & 17 & 29 & 34 & 55 \\
\hline - Nigeria & - & 10 & 43 & 42 & 75 \\
\hline
\end{tabular}

Źródło: R. Bartkowiak, Ekonomia rozwoju, Warszawa 2013, s. 216.

Wraz ze wzrostem ludności miejskiej zwiększa się liczba miast powyżej 10 mln mieszkańców (zob. tab. 4), powstają tzw. megamiasta, gdzie w przypadku krajów słabo rozwiniętych rozrastają się slumsy. W najgorszej sytuacji znajduje się Afryka Subsaharyjska (3/4 mieszkańców miast żyje w slumsach). Stałym problemem slumsów jest wysokie bezrobocie, brak dostępu do podstawowych usług komunalnych, edukacji, ochrony zdrowia, niedożywienie i przestępczość.

Tabela 5: Liczba miast o liczbie mieszkańców powyżej 10 mln.

\begin{tabular}{|c|c|c|c|c|c|}
\hline \multirow[t]{2}{*}{ Grupa krajów } & \multicolumn{5}{|l|}{ Lata } \\
\hline & 1950 & 1970 & 2000 & 2030 & 2050 \\
\hline Świat, w tym: & 1 & 3 & 19 & 34 & 59 \\
\hline - kraje zamożne & 1 & 2 & 4 & 5 & 5 \\
\hline - kraje ubogie & 0 & 1 & 15 & 29 & 54 \\
\hline
\end{tabular}

Źródło: R. Bartkowiak, Ekonomia rozwoju, Warszawa 2013, s. 217.

\section{Podsumowanie}

Zmiany klimatyczne, nierównomierność rozwoju ekonomicznego, które skutkują zawirowaniami na rynkach żywności przynoszą m.in. skutki w postaci niekontrolowanych migracji i lokalnych konfliktów o żywność i wodę. Skutkiem tego może być postępująca destabilizacja w skali świata i napięcia nie tylko 
w krajach dotkniętych głodem, ale również w państwach wysoko rozwiniętych nieprzygotowanych instytucjonalnie na współczesne wyzwania. W wymiarze ekonomicznym narastać mogą praktyki protekcjonistyczne, ograniczanie mobilności osób, eskalacja nierówności w dostępie do zasobów naturalnych i ziemi uprawnej. Należy w sposób znacznie bardziej odpowiedzialny podchodzić do roli państwa jako aktora kształtującego współczesne procesy rozwoju. W tym kontekście wykorzystanie dorobku wypracowanego przez szwedzką szkołę ekonomii oraz skandynawskie studia na pokojem (w tym zwłaszcza ekonomikę pokoju) stać się może podstawą do stworzenia modelu rozwoju wykorzystującego podejście godzące interesy ekonomiczne, przyrodnicze i instytucjonalne. Tworzenie podstaw bezpieczeństwa ekonomicznego państwa musi w sposób pragmatyczny i odpowiedzialny uwzględniać ograniczoność zasobów przyrodniczych i jednocześnie uwzględniać cele społeczne związane z jakością życia ludzi, korzystając z doświadczeń koncepcji państwa dobrobytu.

\section{BIBLIOGRAFIA:}

$\checkmark$ Bartkowiak. R., Ekonomia rozwoju, Warszawa 2013

$\checkmark$ Bauman Z., Ponowoczesność jako źródto cierpień, Warszawa 2001

$\checkmark$ Bauman Z., Kultura w ptynnej rzeczywistości, Warszawa 2001

$\checkmark$ Brauer J., Caruso R., Peace economists and peace economics, Working Paper. Draft (v. 5), 21.11.2011, Draft chapter for Roger MacGintry (ed.) Handbook on Peacebuilding, Londyn 2011

$\checkmark$ Czech S., O legitymizacji państwa dobrobytu, [w:] Dokonania współczesnej myśli ekonomicznej. Teoretyczne ujęcie dobrobytu, (red.) U. Zagóra-Jonszta, Katowice 2012

$\checkmark$ Frejtag-Mika E., Sieradzka K., Granice wzrostu gospodarczego dylematy współczesności, [w:] Globalizacja $i$ regionalizacja we współczesnym świecie. Wyzwania integracji $i$ rozwoju, (red.) E. Molendowski, A. Mroczek, Warszawa 2015

$\checkmark$ Grącik-Zajaczkowski M., Suwerenność w warunkach globalizacji, [w:] Bezpieczeństwo międzynarodowe. Przegląd aktualnego stanu, (red.) K. Żukrowska, Warszawa 2011

$\checkmark$ Kleer J., Dobra publiczne: wczoraj-dziś-jutro, Warszawa 2015

$\checkmark$ Kołodko G., Wędrujacy świat, Warszawa 2008

$\checkmark$ Kot J., Wzrost $i$ rozwój gospodarczy $w$ warunkach globalizacji $i$ umiędzynarodowienia, [w:] Zarzadzanie $i$ gospodarka. Wybrane zagadnienia $i$ procesy, Wybrane aspekty współczesnej gospodarki, (red.) J. Kot, Kielce 2016 
$\checkmark$ Księżopolski K. M., Bezpieczeństwo ekonomiczne - przedmiot badań i praktyka, [w:] Wspótczesne bezpieczeństwo ekonomiczne. Wymiar międzynarodowy, (red.) M. Gębska, M. Kubiak, Warszawa 2016

$\checkmark$ Leszczyński M., Wzrost i rozwój gospodarczy a problem zatrudnienia $w$ gospodarce czarnorynkowej, „Roczniki Ekonomii i Zarządzania”, Tom 10(46), $\mathrm{nr} 2 / 2018$

$\checkmark$ Myrdal G., Przeciw nędzy na świecie, Warszawa 1975

$\checkmark$ Płaczek J., Metodyczne podstawy ekonomiki bezpieczeństwa, [w:] Ekonomika bezpieczeństwa państwa $w$ zarysie, (red.) J. Płaczek, Warszawa 2014

$\checkmark$ Rutkowski W., Nierówności ekonomiczne a rozwój gospodarczy i dobrobyt społeczny, "Ekonomista", nr 2/2016

$\checkmark$ Stachowiak Z., 2012, Teoria i praktyka mechanizmu bezpieczeństwa ekonomicznego państwa. Ujęcie instytucjonalne, Warszawa 2012

$\checkmark$ Weber M., 2002, Gospodarka i społeczeństwo. Zarys socjologii rozumiejacej, Warszawa 2002

$\checkmark$ Woźniak M. G., Holistyczna modernizacja refleksyjna kapitału ludzkiego odpowiedzia na wyzwania $i$ zagrożenia rozwojowe współczesnej fali globalizacji, [w:] Gospodarka Polski 1990-2011. Droga do spójności społeczno-ekonomicznej, Warszawa 2012

$\checkmark$ Żukrowska K., Bezpieczeństwo międzynarodowe. Przegląd aktualnego stanu, Warszawa 2011 